September $\mathbf{- 2 0 2 0}$

\title{
Research Trends in K-12 MOOCs: A Review of the Published Literature
}

Philippos Koutsakas ${ }^{1}$, George Chorozidis ${ }^{2}$, Angeliki Karamatsouki ${ }^{3}$, and Charalampos Karagiannidis ${ }^{4}$ University of Thessaly ${ }^{1,2,4}$, Aristotle University of Thessaloniki ${ }^{3}$

\begin{abstract}
Massive Open Online Courses (MOOCs) appeared in the area of educational technologies in 2008. Until 2013, academic research into MOOCs focused mainly on their application to adults as well as students or graduates of tertiary education. However, since 2013, the rising number of $\mathrm{K}-12$ students enrolled in higher education MOOCs made MOOCs a de facto reality in pretertiary education and triggered universities, governments, and MOOC providers to (a) develop MOOCs specifically designed for pretertiary education, and (b) research their potential and value in $\mathrm{K}-12$ educational settings. This resulted in a notable number of $\mathrm{K}-12 \mathrm{MOOCs}$ and pilot research works in the literature that focused on the potential of MOOCs in compulsory education settings, as well as on their ability to reshape and transform the current educational $\mathrm{K}-12$ framework. This work seeks to (a) trace, analyze, and review the existing literature on $\mathrm{K}-12$ MOOCs, (b) identify representative MOOC implementations, (c) classify and organize research trends and patterns, and (d) reveal MOOCs' potential value and impact on $\mathrm{K}-12$ settings. The research used a narrative literature review methodology in order to critically review and qualitatively analyze twenty-one research publications in a systematic manner. Analysis of relevant works demonstrated that MOOCs, under a set of prerequisites, can be effectively incorporated into and positively affect pretertiary education.
\end{abstract}

Keywords: MOOC, $\mathrm{K}-12$ education, compulsory-age education, narrative review 


\section{Introduction}

Massive open online courses (MOOCs) are online courses aiming for unlimited participation and open access to knowledge via the Web (Kaplan \& Haenlein, 2016). Since their first appearance in 2008, their popularity has increased rapidly, and now it is estimated that more than 11 thousand such courses provide free and open educational content to more than 100 million learners worldwide (Shah, 2018). During these years, research on MOOCs has mainly focused on their application to adults as well as students or graduates of tertiary education, while research on the potential, role, value, and benefits of this new learning tool in pretertiary education was absent until 2013 (Ferdig, 2013).

Since 2012, which was called the year of the MOOC (Pappano, 2012), the growing popularity of MOOCs in higher education triggered discussions about their potential role in lower educational levels (Briggs \& Crompton, 2016), but it was the rising number of $\mathrm{K}-12$ students who enrolled in MOOCs designed for tertiary education that made them a reality in compulsory education (Atkeson, 2014; Guo \& Reinecke, 2014; Stoltzfus, Scragg, \& Tressler, 2015). This increment of K-12 students' participation in MOOCs resulted in a concurrent increase in research interest on $\mathrm{K}-12$ students' perceptions of and experiences with this new, digitally advanced learning tool, as well as the benefits from MOOCs' use in pretertiary education in general (Briggs \& Crompton, 2016; Dermirci, 2014; Horn, 2014; Norris \& Soloway, 2012).

The use of an advanced digital learning tool such as the MOOC in K-12 education is beneficial, not only due to the digital advantages it provides, but also due to the remarkable potential to provide enriched learning opportunities (Briggs \& Crompton, 2016). However, current MOOC types aimed at adult learners often don't meet the needs of K-12 students. The MOOC model for K-12 education must be consistent with pedagogical methods that best fit the ways $\mathrm{K}-12$ students learn, in order to meet the needs of the K-12 educational setting (Bock \& O'Dea, 2013; Briggs \& Crompton, 2016; Locke, 2013). Anecdotal research has demonstrated that MOOCs can be used in pretertiary education as a supplementary resource to traditional instruction, taking a blended approach (Atkeson, 2014; Pannoni, 2014). A blended learning or flipped classroom model based on MOOCs can enhance the learning process and ensure teaching efficiency by combining face-to-face instruction and online learning, taking advantage of the best of what each has to offer (Briggs \& Crompton, 2016; Kassner, 2013). To this extent, MOOCs can effectively be incorporated in school practice in a blended approach, with great potential to benefit students of all ages, providing personalized, engaging, and authentic learning experiences (Briggs \& Crompton, 2016; Locke, 2013).

Incorporating MOOCs in $\mathrm{K}-12$ education has several benefits for both students and teachers. MOOCs can successfully be implemented into existing school infrastructures as foundation courses that could either help students prepare for college or supplement the existing school curriculum. Moreover, MOOCs can be used by students either as remedial courses, to help low-level students, or as additional advanced courses, to offer new teaching subjects at a level beyond the $\mathrm{K}-12$ setting. Furthermore, professional development MOOCs for teachers can alleviate disparities, supplement knowledge, and improve student outcomes (Ferdig, 2013; Locke, 2013; Koxvold, 2014).

The rising number of $\mathrm{K}-12$ students enrolled in higher education MOOCs led universities, governments, and MOOC providers to develop MOOCs specifically for students of pretertiary education (Guo \& Reinecke, 2014; Atkeson, 2014). The first K-12 MOOCs were provided in 2013, through independent initiatives undertaken by well-established universities, educators, and researchers. One year later, European SchoolNet Academy, Canvas, Coursera, and Edx platforms developed and provided courses 
for younger audiences, as well as for K-12 educators. Day by day, more and more K-12 MOOCs are made available and can be integrated into school practice and policy, making research on their potential role and value in pretertiary education much easier than in the past. At the same time, an increasing number of academic papers on K-12 MOOCs appears in the peer-reviewed literature. Since 2013, the few pilot research works that have been carried out have highlighted: (a) the considerable potential MOOCs have to play in $\mathrm{K}-12$ education, and, at the same time, (b) the need for further research and experimentation in order to identify and evaluate the opportunities, benefits, risks, uses, and actual value of this tool in the settings of K-12 education (Yin, Adams, Goble, \& Madriz, 2015; Wartell, 2012).

Aiming to contribute to this promising research area, this paper seeks to trace, analyze, and review the existing literature on $\mathrm{K}-12 \mathrm{MOOCs}$, identify trends and patterns, and classify the academic research on pretertiary educational MOOCs.

Through this process, our work addresses the following research questions:

Q1. What are the most representative $\mathrm{K}-12$ MOOC implementations?

Q2. What are the research trends in the $\mathrm{K}-12$ MOOC field?

Q3. Do MOOCs have a positive impact on $\mathrm{K}-12$ education?

The paper is organized into four sections. Section 1 presents the rationale and defines the objectives and scope of this research. Section 2 presents the methodology used to gather and analyze the literature. Sections 3 and 4 present, analyze, and discuss the research findings and conclusions based on the criteria established by the research questions.

\section{Methodology}

In this section, we describe the methodology used for our work and, more specifically, the methods by which we gathered literature on $\mathrm{K}-12$ MOOCs (data collection) and examined, classified, and analyzed that literature (data classification and analysis).

In our research, we used a narrative literature review methodology to identify and summarize what has been previously published, develop a comprehensive overview of K-12 MOOC research, and reveal new study areas not yet addressed (Ferrari, 2015). Such reviews benefit researchers in planning future studies, as well as developing convenient summaries of the literature on a particular issue (Petticrew \& Roberts, 2008).

Ferrari (2015) claims that the quality of a narrative review may be improved by borrowing elements from the systematic review methodologies. In this respect, the following three key activities for systematic research proposed by Gough, Oliver, and Thomas (2012) were applied to our approach:

1. identifying relevant research

2. critically reviewing and qualitatively analyzing the identified research works in a systematic manner, using evidence tables (Green, Johnson, \& Adams, 2006), and

3. synthesizing research findings into a set of conclusions. 


\section{Data Collection}

Literature discovery searches were systematically conducted, using the key words "MOOC," "MOOCs," "Massive Open Online Course," and "Massive Open Online Courses" in conjunction with "K12," "K-12," "secondary education," "compulsory education," and "high school."

To be included in the corpus, each identified document had to

- focus on MOOCs used in pretertiary education and address $\mathrm{K}-12$ students;

- have been published in a peer-reviewed journal or in conference proceedings, and present primary research studies;

- have been published or been made available online between January 2013 and March 2020; and

- have been written in the English language.

We started searching with Google Scholar (https://scholar.google.com/), Scopus (https://www.scopus.com/), and Research Gate (https://researchgate.net). Then we continued our search using the same keywords in databases more specialized in education sciences, such as ERIC (https://eric.ed.gov/), Microsoft Academic (https://academic.microsoft.com/), IEEE Transactions on Education (https://ieeexplore.ieee.org/xpl/RecentIssue.jsp?punumber=13), and iSeek Education (http://education.iseek.com/iseek/home.page).

Next, we focused our research on educational technology resources, and we used the LearnTechLib Library (https://www.learntechlib.org/) and the Educause Library (https://library.educause.edu/).

Subsequently, we conducted a forward referencing process, similar to the one proposed by Veletsianos and Shepherdson (2016) and Liyanagunawardena et al. (2013), in order to identify relevant research that had cited the papers we had already located. We first located in Google Scholar each of the papers included in our corpus. Google Scholar provides information on how many times a paper is cited and allows researchers to view all papers citing the original. If these new articles met our inclusion criteria, we included them in our corpus. Finally, we examined the references of the papers in our corpus, which were published after 2013, in order to identify any we might have missed.

This data collection process resulted in the identification of twenty-one distinct published works in total, including seven papers published in academic journals and fourteen papers in conference proceedings.

\section{Data Classification and Analysis}

Each of the twenty-one identified publications on K-12 MOOCs was read and analyzed by the authors in a systematic and consistent manner. During this process, for every publication, the authors' team identified and systematically recorded:

1. the focus of the research work

2. the aim of the research work 
3. the research questions that each work attempted to address

4. the research methodology

5. the aspects related to $\mathrm{K}-12 \mathrm{MOOC}$ implementation, and

6. the research findings, identified results and conclusions.

The collected data were organized to address the three research questions. In this respect, each piece of evidence drawn from the twenty-one papers was extracted in the same fashion to help decrease potential bias. Evidence tables were used in order to identify similarities and differences in the analyzed studies. These tables are presented in the following section.

\section{Review of the Literature and Discussion on the Research Findings}

\section{Research Question 1: What are the Most Representative K-12 MOOC Implementations?}

The main goal of this study was to trace and classify the existing K-12 MOOC implementations that emerged during the data collection process. The classification analysis focused on three key aspects: (a) the country where the MOOC is implemented, (b) the teaching subject of the MOOC, and (c) the provider and the learning platform where the MOOC is hosted. Table 1 shows the $\mathrm{K}-12 \mathrm{MOOC}$ implementations classified based on these criteria.

Table 1

K-12 MOOC Implementation Grouping Factors

\begin{tabular}{llc}
\multicolumn{1}{c}{ Publication } & \multicolumn{1}{c}{ MOOC } & $\begin{array}{c}\text { Implementation } \\
\text { Country }\end{array}$ \\
\hline $\begin{array}{l}\text { Politis, Koutsakas, and } \\
\text { Karagiannidis (2017); } \\
\text { Koutsakas, Syritzidou, }\end{array}$ & $\begin{array}{l}\text { A Computer Programming MOOC for Secondary } \\
\text { Karamatsouki, and } \\
\text { Karagiannidis (2018); }\end{array}$ & Greece \\
$\begin{array}{l}\text { Koutsakas, } \\
\text { Karagiannidis, Politis, } \\
\text { and Karasavvidis } \\
\text { (2020) }\end{array}$ & \\
$\begin{array}{l}\text { Blazquez-Merino, } \\
\text { Macho-Aroca, Baizán- } \\
\text { Alvarez, Garcia-Loro, } \\
\text { San Cristobal, Diez, } \\
\text { and Castro (2018) }\end{array}$ & IES Electric Measure MOOC & \\
$\begin{array}{l}\text { Canessa and Pisani } \\
\text { (2013) }\end{array}$ & OpenEya Mathematics MOOC & Spain \\
\hline
\end{tabular}


Cohen and Magen-

Nagar (2016)

De Kereki and Paulós (2014)

De Kereki and

Manataki (2016)

Dziabenko and Persano

Adorno (2017)

Filvà, Guerrero, and

Forment (2014)

Grella, Staubitz

Teusner, and Meinel

(2016)

Grover, Pea, and

Cooper (2016)

Hermans and

Aivaloglou (2017)

Khalil and Ebner (2015)

Kurhila and Vihavainen (2015)

Najafi, Evans, and

Federico (2014)

Nigh, Pytash, Ferdig, and Merchant (2015)

Panyajamorn, Kohda, Chongphaisal, and

Supnithi (2016)

Staubitz, Teusner, and Meinel (2019)

Tomkins, Ramesh, and Getoor (2016)

Yin, Adams, Goble, and Madriz (2015)
Mobile End-Means Robots (MOOC)

Introduction to Astronomy

SM4T: Scratch MOOC for Teens

Uruguay

Code Yourself \& A Programar MOOCs

UK \& Uruguay

Resistors in Series Connections microMOOC

Obligatory Secondary Education MOOC 2014 for Mobile Apps (ESOMOOC14MA)

Introduction to Mobile App Development (IDAM)

Learning to Program in a Playful Way

Germany

Foundations for Advancing Computational Thinking-FACT MOOC

Scratch: Programmeren voor kinderen

Netherlands

Mechanics in Everyday Life MOOC

Austria

Finland

Behavioural Economics in Action BE101X MOOC

Canada

$\mathrm{K}-12$ Teaching in the 21st Century

USA

Chemistry MOOC

Thailand

(rural area)

Learning to Program in a Playful Way MOOC

Germany

Introduction to Object-Oriented Programming in Java MOOC

Computer Science MOOC

USA

Dinosaur Paleobiology MOOC 
The data collection process showed that a significant number of $\mathrm{K}-12$ MOOC implementations are STEM-related courses. More specifically, in Spain, Dziabenko and Persano Adorno (2017) designed a micro-MOOC in the field of physics to introduce school students to the topic of resistors in series connections. The remote experiment VISIR+ of the WebLab at the University of Deusto was incorporated into that micro-MOOC. This course was delivered in the frame of the ERASMUS+ project, "Open discovery of STEM laboratories (ODL)," and the open edX platform was employed to provide the MOOC to students. Similarly, Blazquez-Merino et al. (2018) developed a structured MOOC to optimize learning electricity concepts, magnitudes, and skills. The Virtual Instruments Systems In Reality (VISIR) remote laboratory was incorporated into the MOOC in order to help students move from initial conceptualization to practice-based learning. The MOOC was developed by the Electrical, Electronic and Control Engineering Department of the Spanish Open University (UNED) and provided via the Moodle LMS platform.

In Italy, Canessa and Pisani (2013), designed and implemented a High School Open Online Course (HOOC) in the field of physics and mathematics based on the school curriculum. The MOOC was implemented as a part of the OpenDante project for high school lectures, and the OpenEya software was used in order to archive and share these on-line lessons with students. Likewise, in Austria, Khalil and Ebner (2015) took advantage of a high school STEM MOOC on the subject of physics, mechanics, and aerodynamics sciences in order to apply learning-analytics tools. The MOOC was hosted on the Austrian iMooX platform.

In addition, in the rural areas of Thailand, Panyajamorn, Kohda, Chongphaisal, and Supnithi (2016) used a chemistry MOOC, on the topic of atoms and electronic structures, in conjunction with active learning and flipped learning models. The MOOC was created at the University of Kentucky and delivered via the Coursera platform. In Israel, Cohen and Magen-Nagar (2016) exploited three MOOCs in the field of robotics and astronomy, in combination with a project called Academy Online, in order to integrate academic MOOCs and active learning through the flipped classroom model in the Israeli education system. The MOOCs were developed by the Georgia Institute of Technology and the Open University of Australia and delivered via the Coursera platform.

Most of the collected research papers deal with computer-science MOOC courses. In Germany, Grella, Staubitz, Teusner, and Meinel (2016) designed and ran the MOOC "Learning to Program in a Playful Way," in order to teach young students the Python programming language. The MOOC was hosted by the openHPI learning platform. A few years later, Staubitz, Teusner, and Meinel (2019) redesigned and re-ran "Learning to Program in a Playful Way," and offered at that same time a second MOOC to teach Java programming to high school students. Both MOOCs were given as stretched versions, aiming to lower students' weekly workloads in order to smooth integration. The MOOCs were provided by the MOOC.house, which is based on the openHPI platform.

In Uruguay, De Kereki and Paulós (2014) designed and implemented a MOOC to teach computer programming with Scratch. This MOOC was developed by the Universidad ORT Uruguay as a part of a government project called CEIBAL and offered by the CEIBAL's CREA platform. Two years later, De Kereki and Manataki (2016) in Uruguay and the United Kingdom, collaboratively launched a bilingual MOOC in Spanish and English to teach computational thinking and computer programming with Scratch. The MOOC was developed by the Universidad ORT Uruguay in collaboration with the University of Edinburgh, and the course was implemented using the Coursera platform. 
In the USA, Grover, Pea, and Cooper (2016) designed a MOOC for building awareness of computing as a discipline, and for teaching foundational computational concepts using Scratch. The course was deployed on Stanford University's OpenEdX platform. Additionally, in the USA, Tomkins, Ramesh, and Getoor (2016) developed and demonstrated a computer science MOOC to teach object-oriented computer programming. The course was offered by a for-profit education company. Similarly, in the Netherlands, Hermans and Aivaloglou (2017) created and ran an introductory MOOC to teach Scratch programming concepts and software engineering concepts simultaneously. The MOOC was designed following the pattern from the Delft University of Technology and provided on the edX platform.

In Finland, Kurhila and Vihavainen (2015) implemented a university-level introductory MOOC to high school students in the field of computer science to teach programming concepts. The MOOC was developed at the University of Helsinki and offered on the MOOC.fi platform. Similarly, in Greece, Koutsakas, Karagiannidis, Politis, and Karasavvidis (2020) created and implemented a MOOC to teach structured computer programming. After the first implementation, the MOOC was modified and launched the next year, aiming to address $\mathrm{K}-12$ students' requirements recorded during its first implementation. The MOOC was hosted on the Udemy platform and was accompanied by a Facebook group (Koutsakas, Syritzidou, Karamatsouki, and Karagiannidis, 2018). In Spain, Filvà, Guerrero, and Forment (2014) created and implemented two MOOCs, which were conducted using the same structure and organization but with a significant difference in enrollment. The subject of the MOOCs was common and referred to informatics and technology and, more specifically, to the development of mobile apps. Both MOOCs were provided by the Moodle LMS platform.

The classification of the collected data revealed that most MOOC implementations are STEM-related, and, more specifically, computer science courses. Nevertheless, there is also a small number of MOOC courses in other subject areas. In Canada, Najafi, Evans, and Federico (2014) integrated a behavioural economics MOOC into the school-based course, "Analyzing Current Economic Issues." The course was developed at the University of Toronto and provided on the edX platform. By the same reasoning, Yin, Adams, Goble, and Madriz (2015) used an undergraduate level MOOC on the subject of paleontology which could not otherwise fit into the school curriculum to reach students, who were, in this case, accompanied by their parents. The MOOC was created by the University of Alberta and offered via the Coursera platform. Finally, in the USA, Nigh, Pytash, Ferdig, and Merchant (2015) developed a MOOC in the field of $\mathrm{K}-12$ teaching and learning. The MOOC was intended for teachers and students interested in becoming teachers. The MOOC was designed at Kent State University, in collaboration with Michigan Virtual School, and deployed on Blackboard CourseSites CMS.

\section{Research Question 2: What are the Representative Trends in K-12 MOOCs?}

The second goal of this study was to identify research trends and patterns in the field of K-12 MOOCs, through analysis of the research aims and objectives of existing studies. The classification analysis focused on the role that the $\mathrm{K}-12 \mathrm{MOOC}$ played in the educational process and its resulting value in the $\mathrm{K}-12$ setting.

Analysis of the collected papers as shown in Table 2 revealed three different ways in which MOOCs were successfully implemented into existing school infrastructures: (a) as foundation or advanced placement (hence AP) courses to help students in their preparation for higher education, (b) as supplementary 
courses to the existing school curriculum, or (c) as additional advanced courses, to offer new teaching subjects at a level beyond the $\mathrm{K}-12$ setting.

Table 2

K-12 MOOC Implementation Grouping Factors

\begin{tabular}{|c|c|c|c|c|}
\hline Publication & $\begin{array}{l}\text { AP exam } \\
\text { preparation }\end{array}$ & $\begin{array}{l}\text { Supplementary } \\
\text { to school } \\
\text { curriculum }\end{array}$ & Extra curricular & $\begin{array}{l}\text { Designed for } \\
\mathrm{K}-12\end{array}$ \\
\hline $\begin{array}{l}\text { Politis, Koutsakas, and } \\
\text { Karagiannidis (2017); } \\
\text { Koutsakas, Syritzidou, } \\
\text { Karamatsouki, and } \\
\text { Karagiannidis (2018); } \\
\text { Koutsakas, Karagiannidis, } \\
\text { Politis, and Karasavvidis } \\
\text { (2020) }\end{array}$ & $\mathrm{X}$ & & & Yes \\
\hline $\begin{array}{l}\text { Blazquez-Merino, Macho- } \\
\text { Aroca, Baizán-Alvarez, Garcia- } \\
\text { Loro, San Cristobal, Diez, and } \\
\text { Castro (2018) }\end{array}$ & & $\mathrm{X}$ & & Yes \\
\hline Canessa and Pisani (2013) & $\mathrm{X}$ & & & Yes \\
\hline $\begin{array}{l}\text { Cohen and Magen-Nagar } \\
\text { (2016) }\end{array}$ & & $\mathrm{X}$ & & No \\
\hline De Kereki and Paulós (2014) & & $\mathrm{X}$ & & Yes \\
\hline De Kereki and Manataki (2016) & & $\mathrm{X}$ & & Yes \\
\hline $\begin{array}{l}\text { Dziabenko and Persano Adorno } \\
\text { (2017) }\end{array}$ & & $\mathrm{X}$ & & Yes \\
\hline $\begin{array}{l}\text { Filvà, Guerrero, and Forment } \\
\text { (2014) }\end{array}$ & & $\mathrm{X}$ & & Yes \\
\hline $\begin{array}{l}\text { Grella, Staubitz, Teusner, and } \\
\text { Meinel (2016) }\end{array}$ & & $\mathrm{X}$ & & Yes \\
\hline Grover, Pea, and Cooper (2016) & & $\mathrm{X}$ & & Yes \\
\hline Hermans and Aivaloglou (2017) & & $\mathrm{X}$ & & Yes \\
\hline Khalil and Ebner (2015) & & $\mathrm{X}$ & & Yes \\
\hline Kurhila and Vihavainen (2015) & & & $\mathrm{X}$ & No \\
\hline $\begin{array}{l}\text { Najafi, Evans, and Federico } \\
\text { (2014) }\end{array}$ & $\mathrm{X}$ & & & No \\
\hline $\begin{array}{l}\text { Nigh, Pytash, Ferdig, and } \\
\text { Merchant (2015) }\end{array}$ & & & $\mathrm{X}$ & Yes \\
\hline
\end{tabular}


Panyajamorn, Kohda,

Chongphaisal, and Supnithi

(2016)

Staubitz, Teusner. and Meinel (2019)

Tomkins, Ramesh, and Getoor (2016)

Yin, Adams, Goble, and Madriz (2015) $\mathrm{X}$

No

Yes

$\mathrm{X}$

Yes

$\mathrm{X}$

No

MOOCs implemented into the existing school infrastructures as foundation courses to help students in their preparation for higher education. The data identified four MOOC implementations as foundation courses that support students preparing for college.

Among them, Canessa and Pisani (2013) implemented a High School Open Online Course (HOOC) specifically designed to support the training and basic scientific knowledge of young students. The course helped prepare students for higher education in math and physics. The main goal of the research was to uncover students' and parents' experiences and opinions about the HOOC. The researchers attempted to identify the implications and effects on engagement when high school students were allowed to watch again, at their own place and pace, the same lessons of physics and mathematics held in the classroom. Besides that, the researchers tried to obtain feedback from students on the use and effects of implementing a MOOC in the school setting. There was a quantitative evaluation of the course from students and parents, and qualitative analysis of students' experiences after attending.

In a similar approach, Najafi, Evans, and Federico (2014) integrated a university preparatory economics MOOC not explicitly developed for high school students into a school-based course.. They investigated the engagement of high school students with the learning and assessment components of the course. More precisely, they examined the potential absence or presence of teacher's support in students' learning outcomes, engagement, and persistence during the course. They used a quantitative approach, with pre- and post-questionnaires comparing MOOC-only and blended-mode students.

Tomkins, Ramesh, and Getoor (2016) researched implementation of a preparatory MOOC for Advanced Placement exams in the $\mathrm{K}-12$ context. The students were provided with a year-long computer science high school MOOC. The aim of their research was to understand the applicability of the MOOC model to high schoolers and, at the same time, to gain a better understanding of the teachers' roles as coaches. The research used a machine-learning model to predict students' achievements on AP exams based on their course, forum data, and learning environment.

Finally, Koutsakas et al. (2020) developed and openly offered a computer programming MOOC specifically designed to prepare secondary students for national exams for Greek higher education. The research aimed to observe and analyze students' motives for participation and reasons for early dropout, learning expectations and attitudes toward MOOCs, and students' behaviour within the context of the MOOC. Additionally, the research attempted to determine whether students with special learning disabilities participated in the course and how, if at all, the MOOC impacted them (Politis, Koutsakas, \& 
Karagiannidis, 2017). The research used quantitative analysis of students' learning analytics, and beforeand after-MOOC answers (Koutsakas et al., 2020; Koutsakas et al., 2018).

MOOCs implemented into the school infrastructures as a supplementary resource to the existing curriculum. The data collection process identified twelve MOOC implementations that provided supplementary resources to the existing school curriculum. Five of them were STEMrelated MOOCs and seven were computer programming MOOCs.

The first of the five STEM MOOCs was developed by Khalil and Ebner (2015), which provided a physics, mechanics and aerodynamics (STEM) MOOC supplementary to the school curriculum. This MOOC was specifically designed for high school students. The research aimed to apply learning analytics and qualitative analysis in order to examine both students' attitudes in a STEM MOOC from a pedagogical and psychological point of view, as well as their performances during quizzes.

In a similar approach, Panyajamorn et al., (2016) used a chemistry MOOC developed for adult students to propose and recommend a new hybrid learning model for MOOCs suitable and effective for rural high school students. This chemistry MOOC combined active learning (student-centered model) and a flipped learning approach. The main goal of the research was to examine the impact on students' learning as a result of the proposed MOOC hybrid framework. The research used an experimental quantitative pre- and post-test on the taught subject as well as students' satisfaction questionnaires.

Additionally, Cohen and Magen-Nagar, (2016) used an academic xMOOC to integrate an innovative teaching-learning strategy based on curricular continuity between MOOCs and classroom learning through the flipped classroom model. They examined the contribution of learning strategies as mediator for motivation and a sense of achievement in high school students enrolled in a MOOC. The main goal of the research was to delve into the contribution of the proposed learning strategy to learners' empowerment and capability while engaged in self-regulated learning. The research used an adapted version of the Motivated Strategies for Learning Questionnaire (MSLQ), and the collected data were quantitatively analyzed.

The micro-MOOC, which was specifically designed and developed for $\mathrm{K}-12$ settings by Dziabenko and Persano Adorno (2017), was provided as a supplementary resource to the existing school curriculum, supporting the learning and teaching of physics. The aim of the research, which was still in preliminary stages, was to introduce a new methodology for implementation of remote experiments using MOOCs in order to encourage students to acquire scientific inquiry skills using the $5 \mathrm{E}$ model in micro-MOOCs.

The last of the identified STEM MOOCs was developed by Blazquez-Merino et al. (2018). It provided a structured MOOC on electronics at a secondary school. The MOOC's design used Bloom's taxonomy to ensure the needs of high school students were being met. The main goal of the research was to evaluate students' perceptions and experiences through quantitatively evaluated pre- and post-questionnaires.

Filvà, Guerrero, and Forment (2014) were the first to provide supplementary learning resources through two computer programming MOOCs designed for K-12 students. The aim of their research was to study how massiveness affects participation and interaction in MOOCs. A qualitative experimental research design was used involving a post-test with a control group in order to contrast the samples involved in terms of participation and interaction. 
In a similar work, De Kereki and Paulós (2014) offered a computer programming MOOC specifically designed for $\mathrm{K}-12$ students which provided resources supplementary to the existing school curriculum, aiming to promote the development of procedural thinking and problem-solving skills among $\mathrm{K}-12$ students in Uruguay. The research used a quantitative research methodology. Two years later, De Kereki and Manataki (2016) developed and provided two MOOCs on computer programming aiming to introduce teenagers to programming and computer science, while promoting the development of computational thinking and the use of basic practices in software engineering. Both MOOCs provided additional resources to the existing school curriculum. The research used a quantitative analysis of students' general data and feedback from their course evaluations and qualitative analysis of students' open answers and opinions about the course.

Similarly, Grella et al. (2016) provided a computer programming MOOC designed for young students in order to support secondary education learning and teaching in computer science. Their research aimed to identify the conditions under which the adoption of MOOCs can support secondary education in computer science. To this extent, they collected and quantitatively analyzed high school students' experiences of the MOOC and compared them with the experiences of more than 100,000 adult learners of the openHPI online learning platform. Additionally, the research qualitatively analyzed $\mathrm{K}-12$ teachers' opinions on MOOCs' integration into K-12.

In another research work that adopted a similar approach, Grover, Pea, and Cooper (2016) provided a computer programming MOOC specifically designed for $\mathrm{K}-12$ that aimed to introduce middle-school students to algorithmic thinking and programming. The aim of the research was to identify the variation across middle-school students in learning of algorithmic flow of control, the factors that influence these learning outcomes and the conditions under which the adoption of MOOCs can support learning and teaching in computer science in this educational level. The research used a two-step iterative empirical approach, with the first iteration taking place in a traditional face-to-face classroom setting, and the second in an online version of the MOOC that used a blended model of learning.

Furthermore, Hermans and Aivaloglou (2017) provided an introductory Scratch computer programming MOOC specifically designed for high school students in order to teach programming and software engineering concepts to $\mathrm{K}-12$ students. The research aimed to investigate students' difficulties in programming and engineering concepts, age-related differences in students' performances, and predictions on course completion. The research used a qualitative research methodology, including evaluation and feedback on a weekly basis.

In a similar approach, Staubitz, Teusner, and Meinel (2019) offered two MOOCs specifically designed for high school students in order to support teaching and learning computer programming (Python and Java). The aim of their work was to investigate the use of MOOCs as an instrument to support computer science teachers in secondary schools. The research conducted both quantitative and qualitative analysis.

MOOCs implemented into the existing school curricula as additional (advanced) courses to offer new subjects beyond the K-12 level. The data identified three MOOC implementations developed as additional (advanced) courses to offer new subjects at a level beyond the $\mathrm{K}-12$ setting. 
The $\mathrm{K}-12$ MOOC presented in the research of Yin, Adams, Goble, and Madriz (2015) used an undergraduate university level MOOC in order to investigate students' learning experience. This MOOC implementation was slightly different from the previous MOOCs, as it was targeted at both $\mathrm{K}-12$ students and their parents. The MOOC was about dinosaurs and was provided as an option beyond the school curriculum. The research aimed to gather, analyze, and evaluate the complex realities of children's everyday experiences in the MOOC. The research used a qualitative methodology and generated data via in-depth phenomenological interviews with 12 child-parent couplets from around the world.

Nigh, Pytash, Ferdig, and Merchant (2015) implemented and offered a cMOOC to high school students interested in teaching. Apart from providing a new subject outside the existing school curriculum, the cMOOC addressed students' professional development. It was also offered to pre- and in-service teachers who actively participated and enriched the learning community with their experiences. The purpose of the research was to observe and analyze in-depth $\mathrm{K}-12$ students as they participated, while exploring pre- and in-service teachers participating for professional development reasons. The research collected and analyzed both quantitative and qualitative data.

Finally, Kurhila, and Vihavainen (2015) offered a university computer science MOOC as an extracurricular elective course for high school students, aiming to alleviate the lack of computer science education in Finnish schools. The research aimed to analyze Finnish high school students' behaviour in a university-level computer science MOOC, examine the differences between school students and others, and measure how the participants perceived the difficulty and educational value of a MOOC. The research used a quantitative methodology.

\section{Research Question 3: Do MOOCs Have a Positive Impact in K-12 Education?}

The third goal of this study is determine whether MOOCs have a positive impact on the $\mathrm{K}-12$ education field. In order to identify the potential of MOOCs in compulsory education and the practical and conceptual benefits that MOOCs have to offer to both teachers and students, we followed a classification analysis that emerged from the research findings and conclusions of the existing $\mathrm{K}-12 \mathrm{MOOC}$ implementations.

Although much of the $\mathrm{K}-12 \mathrm{MOOC}$ research is still in the pilot stage, all scientific papers and articles found in the corresponding literature emphasize the potential of MOOCs to reshape the existing school infrastructure by providing a unique learning experience to both students and teachers. On the other hand, the existing MOOC implementations uncover the complex realities and issues of incorporating MOOCs into pretertiary education. High school students have a particular modeling demand as compared to adult learners. Thus, we have to examine the set of prerequisites under which the adoption of MOOCs may have a considerable impact on $\mathrm{K}-12$ education.

Researchers examined in detail students' perceptions, expectations, opinions, attitudes, improvement, and satisfaction regarding participation in MOOCs in order to provide insights into the potential impact of MOOCs on K-12 education. An analysis of the collected papers revealed that all students strengthened their knowledge in the teaching subject (Grover, Pea, \& Cooper, 2016; Najafi, Evans, \& Federico, 2014), improved their performance, and systematically scored higher in their exams (Canessa \& Pisani, 2013; Najafi, Evans, \& Federico, 2014). MOOCs could be a valuable tool to support students in their studies (Canessa \& Pisani, 2013; Author, 2020), through the provision of valuable content and different learning 
strategies that could contribute to a positive transformation of education in general (Grella et al., 2016; Nigh et al., 2015). These courses can provide both students and teachers different learning opportunities and experiences and support new relational configurations (Nigh et al., 2015; Yin et al., 2015). Most students had a very positive overall experience with MOOCs (Author, 2020; Staubitz, Teusner, \& Meinel, 2019), and they found them quite challenging (De Kereki \& Manataki, 2016).

While MOOCs could be a feasible option for $\mathrm{K}-12$ students, there are several concerns about the use of this new learning tool in $\mathrm{K}-12$ education. The analysis of the collected papers showed these concerns could be mitigated in order to provide enriched opportunities for both teachers and students (Staubitz, Teusner, \& Meinel, 2019). The main concern is the ability of young students to assume more control and responsibility for their learning in a self-study manner. While a significant number of $\mathrm{K}-12 \mathrm{MOOC}$ implementations show promise regarding the integration of MOOCs into existing school infrastructures, only highly motivated students thrive in these MOOCs (Canessa \& Pisani, 2013; Kurhila \& Vihavainen, 2015; Najafi et al., 2014; Tomkins et al., 2016).

In order to address this inequality, research has demonstrated that the best way to implement a MOOC in $\mathrm{K}-12$ education is to blend the $\mathrm{MOOC}$ into the traditional classroom, using a didactical approach (i.e., a blended or flipped classroom model) in order to motivate students (Grella et al., 2016; Khalil \& Ebner, 2015; Najafi et al., 2014; Panyajamorn et al., 2016; Tomkins et al., 2016). A teacher's presence in these courses is a core element for student achievement because it may positively influence students to remain on track (Khalil \& Ebner, 2015; Koutsakas et al., 2018; Najafi et al., 2014; Tomkins et al., 2016). Additionally, MOOCs of shorter duration increase the completion rate, and the use of badges of accomplishment encourage students to continue to participate in MOOCs (Khalil \& Ebner, 2015; Staubitz, Teusner, \& Meinel, 2019). Finally, using social media to promote interaction, collaboration, and contribution to the course showed a further way of mitigating some of the concerns (Koutsakas et al., 2018; Panyajamorn et al., 2016).

Using MOOCs in $\mathrm{K}-12$ education is quite challenging but offers an unmatched learning experience to both students and teachers. The existing $\mathrm{K}-12$ MOOC implementations are quite promising and highlight the positive impact that MOOCs offer both teachers and students.

\section{Conclusion}

The proliferation and success of MOOCs in higher education have led to discussions about the potential of this modern learning tool in $\mathrm{K}-12$ education. The unique digital advantages of MOOCs in conjunction with the rising number of $\mathrm{K}-12$ students who enrolled in typical MOOCs for tertiary education leverage both MOOC providers and standalone researchers to develop MOOCs explicitly targeted at $\mathrm{K}-12$ learning environments. This paper attempted to shed light on the existing literature about $\mathrm{K}-12$ MOOCs in order to identify the most representative MOOC implementations, to classify and organize research trends and patterns, and, consequently, to reveal MOOCs' potential value and impact in K-12 education. We used a qualitative narrative literature review methodology in order to develop a comprehensive review of $\mathrm{K}-12 \mathrm{MOOC}$ research.

The analysis of the relevant work on $\mathrm{K}-12$ MOOCs demonstrated that a significant number of $\mathrm{K}-12$ MOOC initiatives are STEM and computer science courses, implemented mostly in Europe and the USA. As far as we can deduce from the collected papers, the vast majority of $\mathrm{K}-12 \mathrm{MOOCs}$ has been designed 
explicitly to meet the needs of $\mathrm{K}-12$ students in order to extend and enhance the existing school curriculum. The analysis of these studies identified students' motivations, expectations, opinions, experiences, and satisfaction regarding their participation in MOOCs in order to gain insight into the issue of using MOOCs in K-12 learning environments. It appears from the review that the most effective option is to embed MOOCs into the existing school infrastructures in a blended approach. It is concluded that MOOCs, under a set of prerequisites, can effectively be incorporated into and positively affect pretertiary education. Teacher's presence, social interaction, and guided learning in a blended school environment seem to be core elements to ensure MOOCs benefit both students and teachers.

Incorporating MOOCs in the area of $\mathrm{K}-12$ education is still in its infancy and many questions remain unanswered. Further research in the field of design, development, implementation, provision, and evaluation of such courses in compulsory-age education is needed in order to uncover the complex realities of $\mathrm{K}-12$ students and teachers participating in the world of MOOCs. 


\section{References}

Atkeson, S. (2014). Harvard-MIT partnership unveils new MOOCs for K-12. Education Week, 34(5), 8. Retrieved from_ https://www.edweek.org/ew/articles/2014/09/24/05moocs.h34.html

Blazquez-Merino, M., Macho-Aroca, A., Baizán-Alvarez, P., Garcia-Loro, F., San Cristobal, E., Diez, G., \& Castro, M. (2018, April). Structured MOOC designed to optimize Electricity learning at Secondary school. In 2018 IEEE Global Engineering Education Conference (EDUCON; pp. 223-232). https://doi.org/10.1109/EDUCON.2018.8363232

Bock, M., \& O’Dea, V. (2013, February 6). Virtual educators critique the value of MOOCs for K-12. Education Week, 32(20), 10. Retrieved from https://www.edweek.org/ew/articles/2013/02/06/20moocs.h32.html

Briggs, S., \& Crompton, H. (2016). Taking advantage of MOOCs in K-12 education: A blended approach. In D. Parsons (Ed.), Mobile and blended learning innovations for improved learning outcomes (pp. 297-309). Hershey, USA: IGI Global. https://doi.org/10.4018/978-15225-0359-0.ch015

Canessa, E., \& Pisani, A. (2013). High school open on-line courses (HOOC): A case study from Italy. European Journal of Open, Distance and E-Learning, 16(1), 131-140. Retrieved from http://www.eurodl.org/materials/contrib/2013/Canessa_Pisani.pdf

Cohen, L. \& Magen-Nagar, N. (2016) Self-regulated learning and a sense of achievement in MOOCs among high school science and technology students. American Journal of Distance Education, 3o(2), 68-79. https://doi.org/10.1080/08923647.2016.1155905

De Kereki, I.F., \& Paulós, V. (2014, October). Sm4t: Scratch MOOC for teens: A pioneer pilot experience in Uruguay. In 2014 IEEE Frontiers in Education Conference (FIE) Proceedings (pp. 1-4). https://doi.org/10.1109/FIE.2014.7044264

De Kereki, I.F., \& Manataki, A. (2016, October). "Code yourself" and "A programar": A bilingual MOOC for teaching computer science to teenagers. In 2016 IEEE Frontiers in Education Conference (FIE) (pp. 1-9). https://doi.org/10.1109/FIE.2016.7757569

Demirci, N. (2014). Kitlesel Açık Çevrimiçi Dersleri (KAÇD) Nedir? Ve öğrenme için bizlere neler vaad ediyor?: KAÇD’ler hakkında inceleme-değerlendirme makalesi [What are Massive Open Online Courses (MOOCs) and what could they promise us for learning?: A review-evaluative article about MOOCs]. Necatibey Eğitim Fakültesi Elektronik Fen ve Matematik Eğitimi Dergisi, 8(1), 231-256. https://doi.org/10.12973/nefmed.2014.8.1.a10

Dziabenko, O., \& Persano Adorno, D. (2017, June). Application of remote experiments in a secondary school using MOOC approach. In 2017 4th Experiment@International Conference (exp.at'17; pp. 191-195). https://doi.org/10.1109/EXPAT.2017.7984358

Ferdig, R.E. (2013). What massive open online courses have to offer $K-12$ teachers and students. Lansing, MI: Michigan Virtual Learning Research Institute. Retrieved from http://media.mivu.org/institute/pdf/mooc report.pdf 
Ferrari, R. (2015). Writing narrative style literature reviews. Medical Writing, 24(4), 230235. https://doi.org/10.1179/2047480615Z.000000000329

Filvà, D.A., Guerrero, M.J.C., \& Forment, M.A. (2014, October). The effects of massiveness on the participation in social technologies: A MOOC in secondary education. In Proceedings of the Second International Conference on Technological Ecosystems for Enhancing Multiculturality (pp. 397-402). https://doi.org/10.1145/2669711.2669930

Gough, D., Oliver, S., \& Thomas, J. (2012). An introduction to systematic reviews. London, England: Sage.

Green, B.N., Johnson, C.D., \& Adams, A. (2006). Writing narrative literature reviews for peerreviewed journals: Secrets of the trade. Journal of Chiropractic Medicine, 3(5), 101-117. https://doi.org/10.1016/So899-3467(07)60142-6

Grella, C.T., Staubitz, T., Teusner, R., \& Meinel, C. (2016). Can MOOCs support secondary education in computer science? In International Conference on Interactive Collaborative Learning (pp. 478-493). https://doi.org/10.1007/978-3-319-50337-0 45

Grover, S., Pea, R., \& Cooper, S. (2016, February). Factors influencing computer science learning in middle school. In Proceedings of the 47th ACM Technical Symposium on Computing Science Education (pp. 552-557). https://doi.org/10.1145/2839509.2844564

Guo, P.J., \& Reinecke, K. (2014). Demographic differences in how students navigate through MOOCs. In Proceedings of the first ACM Conference on Learning@ Scale Conference (pp. 21-30). https://doi.org/10.1145/2556325.2566247

Hermans, F., \& Aivaloglou, E. (2017). Teaching software engineering principles to K-12 students: A MOOC on scratch. In 2017 IEEE/ACM 39th International Conference on Software Engineering: Software Engineering Education and Training Track (ICSE-SEET; pp. 13-22). https://doi.org/10.1109/ICSE-SEET.2017.13

Horn, M. (2014). MOOCs for high school: Unlocking opportunities or substandard learning? Education Next, 14(3), 82-83. Retrieved from https://www.educationnext.org/files/ednext XIV 3 whatnext.pdf

Kaplan, A.M., \& Haenlein, M. (2016). Higher education and the digital revolution: About MOOCs, SPOCs, social media, and the cookie monster. Business Horizons, 59(4), 441-450. https://doi.org/10.1016/j.bushor.2016.03.008

Kassner, L. (2013). Mix it up with blended learning in $K-12$ schools. Metropolitan Educational Research Consortium. Retrieved from https://scholarscompass.vcu.edu/cgi/viewcontent.cgi?article=1009\&context=merc pubs

Khalil, M., \& Ebner, M. (2015). A STEM MOOC for school children-What does learning analytics tell us? In 2015 International Conference on Interactive Collaborative Learning, Florence, Italy, (pp.1217-1221). https://doi.org/10.1109/ICL.2015.7318212 
Koutsakas, P., Syritzidou, E., Karamatsouki, A., \& Karagiannidis, C. (2018, June). Exploring the role of Facebook as collaboration platform in a K-12 MOOC. In International Conference on Technology and Innovation in Learning, Teaching and Education (pp. 31-48). https://doi.org/10.1007/978-3-030-20954-4_3

Koutsakas, P., Karagiannidis, C., Politis, P., \& Karasavvidis, I. (2020). A computer programming hybrid MOOC for Greek secondary education. Smart Learning Environments, 7(1), 1-22. https://doi.org/10.1186/s40561-020-0114-1

Koxvold, I. (2014). MOOCs: Opportunities for their use in compulsory-age education, (Research report). Darlington, England: UK Department of Education. Retrieved from https://assets.publishing.service.gov.uk/government/uploads/system/uploads/attachment d ata/file/315591/DfE_RR355_-Opportunities_for_MOOCs in schools_FINAL.pdf

Kurhila, J., \& Vihavainen, A. (2015). A purposeful MOOC to alleviate insufficient CS education in Finnish schools. ACM Transactions on Computing Education (TOCE), 15(2), 10. https://doi.org/10.1145/2716314

Liyanagunawardena, T.R., Adams, A.A., \& Williams, S.A. (2013). MOOCs: A systematic study of the published literature 2008-2012. The International Review of Research in Open and Distributed Learning, 14(3), 202-227. https://doi.org/10.19173/irrodl.v14i3.1455

Locke, M. (2013). MOOC: Will these four letters change K-12? Scholastic Administrator, 12(6), 39-40. Retrieved from http://www.scholastic.com/browse/article.jsp?id $=3758098$

Najafi, H., Evans, R., \& Federico, C. (2014). MOOC integration into secondary school courses. The International Review of Research in Open and Distributed Learning, 15(5), 306-322. https://doi.org/10.19173/irrodl.v15i5.1861

Nigh, J., Pytash, K.E., Ferdig, R.E., \& Merchant, W. (2015). Investigating the potential of MOOCs in $\mathrm{K}-12$ teaching and learning environments. Journal of Online Learning Research, 1(1), 85-106. Retrieved from https://digitalcommons.kent.edu/ldespubs/7

Norris, C., \& Soloway, E. (2012). Higher ed has MOOCs, but K-12 still needs to catch up. District Administration, 48(9), 96.

Pannoni, A. (2014). MOOCs a new tool for high school teachers. Retrieved from https://www.usnews.com/education/blogs/high-school-notes/2014/10/27/moocs-a-new-toolfor-high-school-teachers

Panyajamorn, T., Kohda, Y., Chongphaisal, P., \& Supnithi, T. (2016, November). The effectiveness and suitability of MOOCs hybrid learning: A case study of public schools in Thai rural area. In 2016 11th International Conference on Knowledge, Information and Creativity Support Systems (KICSS; pp. 1-6). https://doi.org/10.1109/KICSS.2016.7951449

Pappano, L. (2012). The year of the MOOC. The New York Times. Retrieved from https://www.nytimes.com/2012/11/o4/education/edlife/massive-open-online-courses-aremultiplying-at-a-rapid-pace.html?pagewanted=all 
Petticrew, M., \& Roberts, H. (2008). Systematic reviews in the social sciences: A practical guide. Oxford, UK: Blackwell Publishing.

Politis, P., Koutsakas, P., \& Karagiannidis, C. (2017, March). A MOOC for secondary education in Greece. In 1st International Conference on Smart Learning for Community Development (pp.134-147). Retrieved from https://dspace.qou.edu/contents/smart/resources/documents/smart learning.pdf

Shah, D. (2018, December 11). By the numbers: MOOCs in 2018. Retrieved from https://www.classcentral.com/report/mooc-stats-2018/

Staubitz, T., Teusner, R., \& Meinel, C. (2019, April). MOOCs in Secondary Education-Experiments and Observations from German Classrooms. In 2019 IEEE Global Engineering Education Conference (EDUCON) (pp. 173-182). https://doi.org/10.1109/EDUCON.2019.8725138

Stoltzfus, M.W., Scragg. B., \& Tressler, C. (2015). Mind the gap: Connecting K-12 and higher education educators to improve the student experience. Educause Review, 50, 52-53. Retrieved from https://er.educause.edu/-/media/files/article-downloads/erm1528.pdf

Tomkins, S., Ramesh, A., \& Getoor, L. (2016). Predicting post-test performance from online student behavior: A high school MOOC case study. In Proceedings of International Conference on Educational Data Mining (pp. 239-246). Retrieved from http://www.travellingscholar.com/papers/tomkins-edm16.pdf

Veletsianos, G., \& Shepherdson, P. (2016). A Systematic Analysis and Synthesis of the Empirical MOOC Literature Published in 2013-2015. The International Review of Research in Open and Distributed Learning,17(2). https://doi.org/10.19173/irrodl.v17i2.2448

Wartell, M. (2012). A new paradigm for remediation: MOOCs in secondary schools. Educause Review. Retrieved from https://er.educause.edu/articles/2012/11/a-new-paradigm-for-remediationmoocs-in-secondary-schools.

Yin, Y., Adams, C., Goble, E., \& Madriz, L.F.V. (2015). A classroom at home: Children and the lived world of MOOCs. Educational Media International, 52(2), 88-99.

https://doi.org/10.1080/09523987.2015.1053287

\section{Athabasca}

University

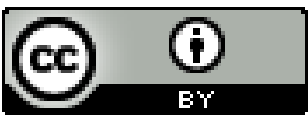

